\title{
Trade of ICT Products, Government, and Economic Growth: Evidence from East Asia-Pacific Region
}

\author{
Lien Phuong NGUYEN ${ }^{1}$, Van Hong Thi PHAM²
}

Received: March 20, 2020 Revised: June 20, 2020 Accepted: July 03, 2020

\begin{abstract}
This study explores the effect of trade of Information Communications Technology (ICT) products and government's role, measured by three factors: Control of corruption, Government effectiveness, and Administrative tax level, on raising the economy across the East AsiaPacific region. Secondary data were collected from the World Bank database of 21 countries over 12 years from 2006 to 2017 . Applying the Panel corrected standard error model and running a robustness check based on the Dynamic panel data method, this research found that the exported ICT products, control of corruption, and government effectiveness could increase the economic income of a country in the region. The paper also provided the evidence indicating that the imported ICT products and the Administrative tax level are two harmful factors for economic growth. The major finding confirmed the useful contribution on improving government quality and its economy. First, improving the economy of a country always poses various challenges to its government. During the past decades, although much of the literature confirmed that exporting ICT products could promote an economy, very few studies investigated the role of Administrative tax level and the Government effectiveness. Second, there are only a few studies exploring the capability of government and the economic growth in the Asia-Pacific region.
\end{abstract}

Keywords: ICT Products, Government's Role, GDP Per Capita

JEL Classification Code: F10, O40, O53

\section{Introduction}

The ICT products are, by definition, information and communication technology goods, which include computers and peripheral equipment, communication, consumer electronic tools, electronic components, as well as other information and technological goods.

${ }^{1}$ First Author and Corresponding Author. Lecturer, Business Administration Department, Faculty of Business Administration, Van Lang University, Vietnam [Postal Address: No. 45, Nguyen Khac Nhu Street, Co Giang Ward, District 1, Ho Chi Minh City, 710000, Vietnam] Email: nguyenphuonglien@vanlanguni.edu.vn

${ }^{2}$ Lecturer, Finance Department, Faculty of Finance and Banking, Van Lang University, Vietnam.

Email: phamthihongvan@vanlanguni.edu.vn

(c) Copyright: The Author(s)

This is an Open Access article distributed under the terms of the Creative Commons Attribution Non-Commercial License (http://Creativecommons.org/licenses/by-nc/4.0/) which permits unrestricted noncommercial use, distribution, and reproduction in any medium, provided the original work is properly cited.
The level of technological progress and economic growth have been discussed for a long time in the related studies. This 'ICT products' variable also plays a key (determining) role in creating economic growth (Link \& Siegel, 2003). Exporting ICT products was considered a motivating factor in increasing the GDP per capita of OECD countries (Falk, 2009). As for developing countries, the change of their economic structures from agriculture into manufacturing technological export also allowed for a greater opportunity to grow their economies (Srholec, 2007). Presently, Asian countries' GDP per capita is still below the global average. Throughout the past three decades, however, the growth in income has varied nation by nation. Lee and Hong (2010) wondered that in the future, how the technological level would contribute to the Asian economies.

The reason for the article to choose the Asia-Pacific region is that this area is one of the main drivers of the global economy, with its countries' own economies facing numerous challenges to implement policies (Akhtar, Hahm $\&$ Malik, 2018). As there have been few arguments in the past that actually shed light on this region, the paper tries to 
investigate the effect of the trade of ICT products as well as other economic factors on the GDP per capita in 21 countries across the Asia-Pacific region. The focus on this region is further justified by the fact that, although it has more than half of the global population, its economy has been slowly decreasing and its inflation rising (ADB, 2016).

Following the introduction, the study starts by presenting a critical summary of the literature about the role of the governance quality, the trade of ICT products and the stability of the economic environment. It then continues to present the theoretical framework, the estimated equation, the way to collect data as well as research variables for testing two hypotheses related to both exported and imported ICT products and government's role. Then, this study proceeds to show the research tables and findings, and provides a discussion about the ICT products and income, followed by the conclusion and limitation of the study.

\section{Literature Review}

In the last two decades, the empirical studies have shed light on the role of exported ICT products being one of the major determinants of GDP per head. The model designed by Mankiw, Romer and Weil (1992) and Yoo (2008) indicated that exporting high-tech products play an important role in increasing economic output. Ustabaş and Ersin (2016) also applied the co-integration test on a panel data of two countries from 1989 to 2014 and confirmed that in the shortrun period, there existed a positive relationship between the export of ICT products and the GDP per capita in South Korea and Turkey. These researchers also noted that, in the long run, the exported ICT products increased GDP per head in South Korea only. Furthermore, the economic crisis could have also affected South Korea's GDP, while it may not have had any effect on GDP per capita in Turkey. Most studies have said that ICT products are a key factor in the economic and social development of the countries due to their positive effects on economic growth, productivity, and human capital (Sepehrdoust, 2019; Pradhan, Mallik \& Bagchi, 2018).

Lee and Xuan (2019) found that innovation and technology reduce the production cost; that is why it is a beneficial factor of total productivity in China. Sadykhanova, Erezhepova, Nurmanova, Aitbembetova, and Bimendiyeva (2019) explored the dynamic data in Kazakhstan and also noted that the development of the high-tech industry plays a crucial role in raising economic growth. Based on the supply side of a production function, Afroz, Muhibbullah, and Morshed (2020) confirmed that, in Malaysia, ICT products can promote the health of human capital in both long-term and short-term periods so that ICT products increase the economic outcome indirectly.

ICT products enabled companies to communicate faster and better so they can cut cost and increase their capacity as well as make better decisions (Vu, 2011). However, until now we do not know well the influence of importing ICT products and how government can drive the factors of exporting and importing such products to promote economic growth Furthermore, Aghaei and Nasab (2009) noted that the influence of ICT products on the GDP per head was mixed depending on the analysis method as well as the studied countries' geographies. Most previous researchers determined the GDP per capita by two major factors: exogenous and endogenous proxies based on the CobbDouglas production function. Solow (1956) indicated that the first factor, the exogenous variables, were related to financial capital, human capital and technology. The Landau (1985) critically argued that technological progress was influenced by the development of the labor force, which also increased the investment financial capita. Furthermore, other scholars debated that government was a crucial factor that drove the whole economic element and led the GDP per capita of each economy (Mankiw, Romer \& Weil, 1992; Cooray, 2009; Dzhumashev, 2014). In past literature, the influence of the exogenous and endogenous variables, and the role of government on economies were complex and diverse (see Table 1).

Most previous research also applied the Ordinary Least Square (OLS) method to define the GDP per work. Some other studies employed the Generalized method of moments (GMM), the Fixed-effect (FEM), or the Random-effect model (REM) to fix the endogeneity problem. However, because of the small data set, the more appropriate method would be the Panel corrected the standard error (PCSE) model and the dynamic panel data, which can provide less bias than the fixed-effect model Baltagi, 2005; Lien, 2015). Previous studies left two gaps. First, there was little research that applied the PCSE method for a short data set. Second, there has been a scarcity of studies that actually explored the role of government in three aspects: administrative tax burden measuring by 'Total hours spent paying taxes per year'

Table 1: Summary of GDP per capita determination

\begin{tabular}{|l|l|l|}
\hline \multicolumn{1}{|c|}{$\begin{array}{c}\text { Factor } \\
\text { Effect }\end{array}$} & \multicolumn{1}{|c|}{$\begin{array}{c}\text { Exogenous (ICT } \\
\text { products) }\end{array}$} & $\begin{array}{c}\text { Endogenous } \\
\text { (Government role, } \\
\text { corruption) }\end{array}$ \\
\hline Negative & Inflation & $\begin{array}{l}\text { Low governance, } \\
\text { corruption }\end{array}$ \\
\hline Positive & $\begin{array}{l}\text { R\&D in high-tech, } \\
\text { export of ICT } \\
\text { products, innovative } \\
\text { activities, export share } \\
\text { of high-tech products, } \\
\text { export + import }\end{array}$ & $\begin{array}{l}\text { Control of corruption, } \\
\text { Government } \\
\text { spending, } \\
\text { High governance }\end{array}$ \\
\hline Neutral & Inflation & \\
\hline
\end{tabular}


hereafter called the 'Administrative tax level-ATL' variable; control of corruption indicator; and the index of effectiveness of government, simultaneously. In this paper, we developed a model that determines the countries' economic growth by the following input factors: labor and financial capital that could be measured by ICT export and ICT import products (it is also called the 'Trade of ICT products'). These proxies would explain the level of technological progress as well as human capital capability. Based on the above argument, this study designed the first hypothesis as:

H1: Trade of ICT products has variance effects on the GDP per capita depends on the quality of the Government.

Furthermore, the economic status can provide a strong or weak effect on economic productivity. To evaluate the economic stability, we applied the inflation rates, which were collected and calculated by the World Bank. Furthermore, there is a riche debate about the complicated role of corruption in economic growth. Some previous researchers have said that corruption has a 'greasing' role and a 'salting' role in the wheels of an economy, depending on different groups of countries. Méon and Weill (2010) confirmed the hypothesis that corruption is 'efficient grease' in extremely inefficient countries and it is less damaging to efficiency in countries with less institutional quality. D'Agostino et al. (2012) and Ugur (2014) indicated that corruption suggests weakness of institutional quality, and has a potentially harmful effect on economic growth. Moreover, D'Agostino et al. (2016) revealed that, although corruption does not directly affect the growth of economies, its interaction with spending on investment and military negatively affects economic growth.

To understand the regime of corruption that affects other activities, previous authors designed two major models. First, the agency model uses the equilibrium equation to balance the interests of officials and their elected power and explain the existence of corruption and its influence on economic activities (Barro, 1973; Mauro, 1995; Bird, Martinez-Vazquez and Torgler, 2008; Beekman, Bulte and Nillesen, 2013; Angelucci \& Russo, 2015; Aghion et al., 2016). Second, the resource allocation model applied and expanded the production function to show the causes of corruption and its impact on economic outcomes (Ajaz \& Ahmad, 2010; Brianzoni, Campisi \& Russo, 2018). We were also aware that the external environment measuring the political policies and government capability could be the control variables that affect total productivity. In this study, we used the indicator that measured the total hours per year firms have to spend on their compliance on following tax administration procedures as one of the control vectors. Two other factors which should be applied to indicate the role of governance quality are: The control of corruption indicator and the index of government effectiveness ranging from -2.5 to 2.5 . These indicators represent the perception of private, elite governors and foreign investors about the public powers exercising for private firms. The second hypothesis is therefore presented below.

H2: The level of government quality has a complex influence on the economic growth (GDP per capita).

\section{Methodology}

To examine the economic growth, in early studies, almost authors applied the Cobb and Douglas's (1928) production function: $\mathrm{Y}=\mathrm{F}(\mathrm{K}, \mathrm{L})$. Solow (1956) expanded this model by adding the technology process : $Y=A K^{\alpha} L^{1-\alpha}$. Mankiw, Romer and Weil (1992) argued the role of stock of human capital on the economic income and defined the equation to explain the growth as seen as below:

$$
\begin{aligned}
y(t)= & K(t)^{\alpha} H(t)^{\beta}(A(t) L(t))^{1-\alpha-\beta} \\
& 0<\alpha<1, \alpha+\beta<1,
\end{aligned}
$$

Based on this model, Cooray (2009) developed the below equation with the size of government in explanation the government role:

$$
y(t)=A k(t)^{\alpha} h(t)^{\beta}\left(g(t) e^{\mu \theta}\right)^{\gamma}
$$

From the previous discussion, the output, which was an economic factor explaining the growth, was used: GDP per capita. The inputs are exogenous factors such as A stands for a level of technological progress, $\mathrm{K}$ for capital resource, and $\mathrm{L}$ for the labour force. However, both Mankiw, Romer and Weil (1992) as well as Cooray (2009) considered that the technological level and the knowledge of human capital are all endogenous factors, which depended on the income. Furthemore, Cooray (2009) noted that the dimention of the Government would depend on their expenditure and their quality of governance, measured by six governance indicators, all of which may be the proxies explaining the different growth of each country: government effectiveness; control of corruption; rule of law; quality of regulation; political stability and absence of violence/terrorism; and voice and accountability. From this research, we see that among six governance indicators, both 'control of corruption' and 'government effectiveness' can represent the six once for that these two indicators were the results from remaining of the four indicators in a country. 
Previous papers had already developed the regression models for estimating the economic growth with the numerous economic variables. Because of that, our study would focus on the structure of the model with ICT export and import products representing the role of financial and human capital factors. The variables for the regression model were determined as follow: One control variable, namely, the inflation rate, would be about the economic status; and three others indicating the role of the quality of government: Time for paying taxes per year (in hours) (Administrative tax level), Control of corruption, and Effectiveness of government. The base model, with the argument that an economy depends on their financial, human capital and stability environment, would be designed as seen as below.

$$
\begin{aligned}
\operatorname{GDPpp}_{i, t} & =\beta_{0}+\beta_{1} \text { ICTtexp }_{i, t}+\beta_{2} \text { ICTimp }_{i, t} \\
& +\beta_{3} I N F_{i, t}+\varepsilon_{i, t},
\end{aligned}
$$

Trying to further experiment the role of quality of government, the study added three more proxies: Time for paying taxes per year (in hours), Control of corruption, which present the capability of government in practicing their policies, and finally Effectiveness of government, which indicates the quality of policy of governance. These indicators always impacted both directly and indirectly on the activities of an economy.

$$
\begin{aligned}
\operatorname{GDPpp}_{i, t} & =\beta_{0}+\beta_{1} \text { ICTtexp }_{i, t}+\beta_{2} \operatorname{ICTimp}_{i, t}+\beta_{3} I N F_{i, t} \\
& +\beta_{4} A T L_{i, t}+\beta_{5} C C_{i, t}+\beta_{6} G E_{i, t}+\varepsilon_{i, t}
\end{aligned}
$$

where GDPpp referred to the nature logarithm of GDP per capita in 2011 (in PPP-constant USD); ICTtexp and ICTimp to the $\%$ of ICT export and import products; INF to inflation annual ratio; ATL to tax payment per time hours to comply with the procedure of administration (it is also called "Administrative tax level"). And as for the other two factors: Control of corruption (CC) and Government effectiveness (GE) were used to determine the quality of government, the data of which was collected mainly from the World Bank, with the numbers ranked from -2.5 to 2.5 . Finally, the $\varepsilon$ stood for un-observation error of cross-panel data, $i$ for country and $t$ for year. Based on previous studies and the above hypotheses, this paper expected that

$$
\beta_{1}, \beta_{5}, \beta_{6}>0 \text { and } \beta_{2}, \beta_{3}, \beta_{4}<0 \text {. }
$$

\section{Empirical Results and Discussion}

Creswell (2009) indicated that researchers always begin the scientific method with theory, then collect data that supports or refutes their theory, and make any necessary revisions before adding a test so that the data are collected on an instrument that measures attitudes, and the information is analyzed using statistical procedures and hypothesis testing. First of all, this study extracted the data set of the "World development indicator" from the World Bank's website to collect the first index of the percentage of total ICT export and import products (ICTtexp and ICTimp); afterwards, it chose an inflation rate that presented the stable economic environment. Next, the paper selected the total compliance level index (Administrative tax level-ATL), which measured the total hours spent paying taxes per year, contained inside the PWC's yearly reports and also summarized into the 'doing business report' published by the World Bank. Finally, it picked up two indicators: Control of corruption (CC) and Government effectiveness (GE) from the World Wide Governance Indicators developed by the World Bank. The above variables such as ATL, CC and GE all represented the capability of government quality. Table 2 shows those variables in this study.

GDPpp $=$ GDP per capita power parity. GDPpp is defined as gross domestic products converted into international dollars using purchasing power parity rates. The data in kept constant, calculated using 2011's value of US dollars.

ICTtexp $=$ ICT export products measured by the $\%$ of total goods export that included computers, peripheral equipment and electronic components.

ICTimp = ICT import products measured by the $\%$ of total goods import that included computers, peripheral equipment and electronic components.

$\mathrm{INF}=$ inflation rate measured by consumer price index, reflecting the annual percentage change in costs.

$\mathrm{ATL}=$ total compliance level (it is also called "Administrative tax level") measured by tax-paying hours per year reported by the Price Waterhouse Coopers' reports and the World Bank in its "Doing business report"

$\mathrm{CC}=$ Control of corruption indicator evaluated by the World Bank ranging from -2.5 to 2.5. Bad corruption control leading to the highest existing point of corruption was valued at -2.5 ; while the best index of corruption control with the lowest corruption appearance was at 2.5 .

$\mathrm{GE}=$ Government effectiveness index with the range from the lowest level of effectiveness at -2.5 and the best at 2.5 .

Owing to the lack of data in the hours spent for paying taxes and the ICT export and import products of some countries in the region, the paper only attempted to study only the 21 countries below, despite the Asian-Pacific region having as many as 49 nations (see Appendix Table A2).

Table 2 shows that Singapore is a country, which had the highest income and effectiveness of governance indicators. On the other hand, Hong Kong was the nation holding the highest number in ICT export and Import ratio. New Zealand got the top rank in handling corruption. Meanwhile, other 
Table 2: Summary Description of Variables

\begin{tabular}{|c|c|c|c|c|c|}
\hline Variable & Obs & Mean & Std. Dev. & Min & Max \\
\hline GDPpp (USD) & 252 & 22166.700 & 22403.02 & $\begin{array}{c}1712.53 \\
\text { ( Nepal } 2006 \text { ) }\end{array}$ & $\begin{array}{c}87760.37 \\
\text { ( Singapore } 2017 \text { ) }\end{array}$ \\
\hline $\begin{array}{l}\text { ICTtexp } \\
\text { (\% of total goods exports) }\end{array}$ & 241 & 10.064 & 14.596 & $\begin{array}{c}0.001 \\
(\text { Nepal } 2015) \\
\end{array}$ & $\begin{array}{c}51.672 \\
\text { ( Hong Kong } 2017 \text { ) } \\
\end{array}$ \\
\hline $\begin{array}{l}\text { ICTimp } \\
\text { (\% of total goods imports) }\end{array}$ & 243 & 11.281 & 11.152 & $\begin{array}{c}1.294 \\
(\text { Samoa 2009) } \\
\end{array}$ & $\begin{array}{c}51.859 \text { ( Hong Kong } \\
2017 \text { ) } \\
\end{array}$ \\
\hline $\begin{array}{l}\text { INF } \\
\text { (annual \%) }\end{array}$ & 240 & 4.549 & 4.254 & $\begin{array}{c}-1.404 \\
(\text { Armenia } 2016)\end{array}$ & $\begin{array}{c}24.997 \\
\text { ( Cambodia } 2008 \text { ) }\end{array}$ \\
\hline $\begin{array}{l}\text { ATL } \\
\text { (hrs) }\end{array}$ & 251 & 251.460 & 200.899 & $\begin{array}{c}44.500 \\
\text { ( Hong Kong 2016-2017) } \\
\end{array}$ & $\begin{array}{c}1050.000 \\
(\text { Vietnam 2006-2010) }\end{array}$ \\
\hline $\begin{array}{l}\mathrm{CC} \\
\text { (Indicator, range from }-2.5 \text { to } 2.5 \text { ) }\end{array}$ & 250 & 0.155 & 1.051 & $\begin{array}{c}-1.340 \\
(\text { Tonga } 2006)\end{array}$ & $\begin{array}{c}2.391 \\
(\text { New Zealand 2009) }\end{array}$ \\
\hline $\begin{array}{l}\mathrm{GE} \\
\text { (Indicator, range from }-2.5 \text { to } 2.5 \text { ) }\end{array}$ & 250 & 0.357 & 0.939 & $\begin{array}{c}-1.054 \\
(\text { Nepal } 2015)\end{array}$ & $\begin{array}{c}2.437 \\
\text { ( Singapore 2008) }\end{array}$ \\
\hline
\end{tabular}

Sources: World Development Indicators, Worldwide Governance Indicators, and Paying Taxes index.

Table 3: Correlation Matrix

\begin{tabular}{|c|c|c|c|c|c|c|c|}
\hline Variable & LgGDPpp & ICTtexp & ICTimp & INF & ATL & CC & GE \\
\hline LgGDPpp & 1 & & & & & & \\
\hline ICTtexp & $\begin{array}{c}0.317 \\
(0.000)^{*+* *}\end{array}$ & 1 & & & & & \\
\hline ICTimp & $\begin{array}{c}0.363 \\
(0.000)^{*+* *}\end{array}$ & $\begin{array}{c}0.949 \\
(0.000)^{*+* *}\end{array}$ & 1 & & & & \\
\hline INF & $\begin{array}{c}-0.337 \\
(0.000)^{*+*}\end{array}$ & $\begin{array}{c}-0.249 \\
(0.000)^{* \ldots *} \\
\end{array}$ & $\begin{array}{c}-0.243 \\
(0.000)^{*+*+*}\end{array}$ & 1 & & & \\
\hline ATL & $\begin{array}{c}-0.447 \\
(0.000)^{* * * *}\end{array}$ & $\begin{array}{l}-0.215 \\
(0.001)^{*+*}\end{array}$ & $\begin{array}{c}-0.264 \\
(0.000)^{*+* *}\end{array}$ & $\begin{array}{c}0.422 \\
(0.000)^{* * * *}\end{array}$ & 1 & & \\
\hline $\mathrm{CC}$ & $\begin{array}{c}0.720 \\
(0.000)^{* * * *} \\
\end{array}$ & $\begin{array}{l}0.328 \\
0.000\end{array}$ & $\begin{array}{c}0.444 \\
(0.000)^{*+* *+}\end{array}$ & $\begin{array}{c}-0.387 \\
(0.000)^{+* * *}\end{array}$ & $\begin{array}{c}-0.426 \\
(0.000)^{*+*}\end{array}$ & 1 & \\
\hline GE & $\begin{array}{c}0.835 \\
(0.000)^{*+*}\end{array}$ & $\begin{array}{c}0.454 \\
(0.000)^{* * * *}\end{array}$ & $\begin{array}{c}0.529 \\
(0.000)^{*+* *}\end{array}$ & $\begin{array}{c}-0.412 \\
(0.000)^{* * *}\end{array}$ & $\begin{array}{c}-0.405 \\
(0.000)^{* * * *}\end{array}$ & $\begin{array}{c}0.926 \\
(0.000)^{*+*+*}\end{array}$ & 1 \\
\hline
\end{tabular}

Note: ${ }^{*} p<0 .,{ }^{* *} p<0.05$ and ${ }^{* * *} p<0.01$

Sources: World Development Indicators, Worldwide Governance Indicators, and Paying Taxes index.

developing countries, namely, Cambodia and Vietnam, kept the highest figures for inflation rate and total hours spent on paying taxes respectively. Through Table 2 , we can see the critical question: Is there a chance that the difference in income may depend on the difference in the quality of government and the current economic status? (see Table 2).

Before running the correlation matrix, this study had conducted the nature of logarithm of the GDP per capita in order to be less biased in cross-sectional data from the large countries.
Table 3 shows that the dependent variable GDPpp had a strong correlation with the other independent variables. Through table 3, the inflation rate and administrative tax level are the two damaging factors that can reduce income. Except for these two harmful factors, the remaining variable was a supported factor for the increase in the GDP per head of an economy. Furthermore, among the dependent variables there appeared to be a close correlation, which was a reason for running a Variance inflation factor (VIF) test; and representing the increase in variance due to the correlation 
between the predictors and thus resulting in multicollinearity (see table 3). In this case, the VIF should be 1/( 1-0.952) $=10.256$. A rule of thumb was that if $\mathrm{VIF}>10$ then the multicollinearity was high (Hair, Black, Babin, \& Anderson, 2014; Lien, 2018).

On the basic model (equation 3), the research tried to examine the influence of the ICT products and the status of the economy. The results implicated that the both variables 'ICT export products' and 'ICT import products' are beneficial factors in increasing the GDP per capita with significance at $10 \%$ and $5 \%$, respectively, while the inflation rate negatively affected income per capita, but without any significance (see Table 4 - eq.3). These results provided evidence supporting the one side of the first hypothesis only. These findings also support the empirical research of the previous authors such as Sepehrdoust (2019) and Pradhan, Mallik, and Bagchi (2018). To investigate the role of government, the paper conducted an extended model by entering three more factors: ATL, CC and GE.

Table 4 - eq. 3' shows that the ICT export products continued to be a useful factor in promoting economic growth. This table also indicates that when the government increases the index of corruption control and the index of government effectiveness, the GDP per capita rises from $\mathrm{X}$ (USD) to $\mathrm{X}+(0.06)$ (USD) and $\mathrm{X}+(0.284)$ (USD). The finding also confirmed the theory named 'Sand the wheel of corruption' (Binh \& Lien, 2019). Meanwhile, when the hours spent paying taxes per year increases by one hour (Administrative tax level), the GDP per capita will decrease. Furthermore, the ICT import products were also shown to change from positively into negatively affecting the GDP per capita, however only with only a small level of impact. Thus, it can be concluded that the finding from running extended model, equation 3' supported the first and second hypothesis (see table 4 - eq.3').

Since the 240 observations are only considered a small panel data, the research applied the panel corrected standard error (PCSE) method for producing the linear regression model to predict the effects of the ICT products and government's role in promoting GDP per capita. For robustness check, this study used the Dynamic panel data method to compare the linear regression results with the PCSE' results. The findings provided the similar effects of the studied factors in both models (see Appendix Table A1).

Table 4: PCSE analysis results

\begin{tabular}{|c|c|c|c|c|}
\hline \multirow[b]{2}{*}{ Variables } & \multicolumn{2}{|c|}{ Based model (eq. 3) } & \multicolumn{2}{|c|}{ Extended model (eq. 3') } \\
\hline & $\begin{array}{l}\text { Coef. } \\
\text { Std. Err. }\end{array}$ & $\begin{array}{l}\text { Computed z } \\
\text { Statistic }^{*}\end{array}$ & $\begin{array}{l}\text { Coef. } \\
\text { Std. Err. }\end{array}$ & $\begin{array}{l}\text { Computed } \mathrm{t} \\
\text { statistic }^{*}\end{array}$ \\
\hline & \multicolumn{2}{|c|}{ Dependent variable: $L g \_G D P p p$} & \multicolumn{2}{|c|}{ Dependent variable: Lg_GDPpp } \\
\hline ICTtexp & $\begin{array}{c}0.004 \\
(0.002)\end{array}$ & $\begin{array}{c}1.860 \\
(0.064)^{*}\end{array}$ & $\begin{array}{c}0.003 \\
(0.002)\end{array}$ & $\begin{array}{c}2.120 \\
(0.034)^{* *}\end{array}$ \\
\hline ICTimp & $\begin{array}{c}0.007 \\
(0.003)\end{array}$ & $\begin{array}{c}2.400 \\
(0.016)^{* *}\end{array}$ & $\begin{array}{l}-0.003 \\
(0.002) \\
\end{array}$ & $\begin{array}{l}-1.690 \\
(0.091)^{*}\end{array}$ \\
\hline INF & $\begin{array}{l}-0.001 \\
(0.001)\end{array}$ & $\begin{array}{l}-0.860 \\
(0.390)\end{array}$ & $\begin{array}{c}0.002 \\
(0.001)\end{array}$ & $\begin{array}{c}1.410 \\
(0.160)\end{array}$ \\
\hline ATL & & & $\begin{array}{c}-0.0003 \\
(0.000)\end{array}$ & $\begin{array}{c}-7.600 \\
(0.000)^{* * *}\end{array}$ \\
\hline $\mathrm{CC}$ & & & $\begin{array}{c}0.060 \\
(0.026)\end{array}$ & $\begin{array}{c}2.320 \\
(0.020)^{* *}\end{array}$ \\
\hline GE & & & $\begin{array}{c}0.284 \\
(0.038)\end{array}$ & $\begin{array}{c}7.560 \\
(0.000)^{* * *}\end{array}$ \\
\hline cons & $\begin{array}{c}3.971 \\
(0.022)\end{array}$ & $\begin{array}{l}182.000 \\
(0.000)^{* * *+}\end{array}$ & $\begin{array}{c}4.084 \\
(0.027)\end{array}$ & $\begin{array}{l}152.340 \\
(0.000)^{*+*}\end{array}$ \\
\hline Number of observation & \multicolumn{2}{|c|}{229} & \multicolumn{2}{|c|}{226} \\
\hline$R 2$ & \multicolumn{2}{|c|}{0.9913} & \multicolumn{2}{|c|}{0.9926} \\
\hline Wald chi2 & \multicolumn{2}{|c|}{107.15} & \multicolumn{2}{|c|}{1331.30} \\
\hline Prob > chi2 & \multicolumn{2}{|c|}{0.000} & \multicolumn{2}{|c|}{0.000} \\
\hline
\end{tabular}

$z$ statistics in parentheses: ${ }^{*} p<0.1,{ }^{* *} p<0.05,{ }^{* * *} p<0.01$ 


\section{Conclusions}

To investigate the role of the trade of ICT products and government in 21 Asian-Pacific countries from 2006 to 2017, this paper applied a panel corrected standard error method and then found that the ICT export products, the control of corruption and the effectiveness of the government are beneficial factors which promoted the GDP per capita across this region. Meanwhile, the total hours for paying taxes (Administrative tax level) and the imported ICT products were adverse variables for economic growth. The results also supported Binh and Lien (2019)'s 'Sand the wheel' theory of corruption effects: less corruption significantly encourage the economic growth. Furthermore, the dynamic panel data model also proved to be able to fix the endogenous phenomenon well, as well as provided the same results with the findings by employing the PCSE analysis.

Therefore, the findings suggest that the governments in the Asian-Pacific region should focus on supporting tax payers by way of providing faster administration procedures, as well as employing more anti-corruption methods in order to improve their economies. Because of the limitation in data collection, the research only discussed 21/49 nations across the region. In addition, this research could further be expanded into various other regions such as the EU, or the G20 countries in order to have a more generalized view about the role of ICT products as well as the role of the governments on economic growth in these different regions.

\section{References}

ADB. (2016). Asian economic integration report 2016. Manila, Philippines. Retrieved December 12, 2019 from https://www. adb.org/publications/asian-economic-integration-report-2016.

Afroz, R., Muhibbullah, M., \& Morshed, M. N. (2020). Impact of information and communication technology on economic growth: Evidence from developing countries. Journal of Asian Finance, Economics and Business, 7(4), 155-162. https://doi. org/10.13106/jafeb.2020.vol7.no4.155

Aghaei, M., \& Nasab, E. H. (2009). The Effect of ICT on Economic Growth: Further Evidence. International Bulletin of Business Administration, (5), 46-56. Retrieved Febuary 7, 2020 from http://www.eurojournals.com/IBBA.htm46.

Aghion, P., Akcigit, U., Cagé, J., \& Kerr, W. R. (2016). Taxation , corruption, and growth. European Economic Review, 86(2016), 24-51.

Ajaz, T., \& Ahmad, E. (2010). The effect of corruption and Governance on Tax revenue. Pakistan Development Review, 49(4), 405-417.

Akhtar, S., Hahm, H., \& Malik, H. A. (2018). Economic and social survey of Asia and the Pacific 2018: Mobilizing finance for sustained, inclusive and sustainable economic growth. United
Nations Publication. Bangkok: United Nations publication. Retrieved Febuary 5, 2020 from https://www.unescap.org/sites/ default/files/publications/Survey2018_Final_0.pdf.

Angelucci, C., \& Russo, A. (2015). Petty corruption and citizen feedback. IEB Working Paper N. 2015/25. New York. Retrieved June, 19, 2018 from http://ieb.ub.edu/wp-content/ uploads/2018/04/2015-IEB-WorkingPaper-25.pdf

Baltagi, B. H. (2005). Econometric analysis of panel data $\left(3^{\text {rd }}\right.$ ed.). West Sussex, England: JohnWiley \& Sons Ltd.

Barro, R. J. (1973). The control of politicians: An economic model. Public Choice, 14, 19-42.

Beekman, G., Bulte, E. H., \& Nillesen, E. E. M. (2013). Corruption and economic activity: Micro level evidence from rural Liberia. European Journal of Political Economy, 30(2013), 70-79. DOI: 10.1016/j.ejpoleco.2013.01.005.

Binh, T. N., \& Lien, N. P.. (2019). The impact of tax rate, compliance burden and corruption control on tax ratio: evidence from emerging Asian countries from 2004 to 2015. New Zealand Journal Of Taxation Law And Policy, 25(3), 285-307.

Bird, R. M., Martinez-Vazquez, J., \& Torgler, B. (2008). Tax Effort in Developing Countries and High Income Countries: The Impact of Corruption, Voice and Accountability. Economic Analysis and Policy, 38(1), 55-71. https://doi.org/10.1016/ S0313-5926(08)50006-3

Brianzoni, S., Campisi, G., \& Russo, A. (2018). Corruption and economic growth with non constant labor force growth. Communications in Nonlinear Science and Numerical Simulation, 58(2018), 202-219. DOI: 10.1016/j. cnsns.2017.07.007.

Cobb, C. W., \& Douglas, P. H. (1928). A Theory of Production. American Economic Association, 18(1), 139-165.

Cooray, A. (2009). Government expenditure, governance and economic growth. Comparative Economic Studies, 51(2009), 401-418.

Creswell, J. W. (2009). Research design: Qualitative, quantitative, and mixed methods approaches ( $3^{\text {rd }}$ ed.). California: Sage Publicatiions, Inc.

D’Agostino, G., Dunne, J. P., \& Pieroni, L. (2016). Government Spending, Corruption and Economic Growth. World Development, 84(1997), 190-205. DOI: https://doi. org/10.1016/j.worlddev.2016.03.011.

D’Agostino, G., Dunne, J. P., \& Pieroni, L. (2012). Corruption, military spending and growth. Defence and Peace Economics, 23(6), 591-604.

Dzhumashev, R. (2014). Corruption and growth: The role of governance, public spending, and economic development. Economic Modelling, 37, 202-215. https://doi.org/10.1016/j. econmod.2013.11.007.

Falk, M. (2009). High-tech exports and economic growth in industrialized countries. Applied Economics Letters, 16(10), 1025-1028. https://doi.org/10.1080/13504850701222228. 
Hair, J. F. J., Black, W. C., Babin, B. J., \& Anderson, R. (2014). Multivariate data analysis (7th ed.). London, UK: Pearson Education Limited.

Landau, D. (1985). Government Expenditure and Economic Growth in the Developed Countries: 1952-76. Public Choice, 47(3), 459-477. Retrieved June 5, 2017 from http://www.jstor.org/ stable/30024560.

Lee, J. W., \& Xuan, Y. (2019). Effects of technology and innovation management and total factor productivity on the economic growth of China. Journal of Asian Finance, Economics and Business, 6(2), 63-73. https://doi.org/10.13106/jafeb.2019. vol6.no2.63.

Lee, J. W., \& Hong, K. (2010). Economic growth in Asia: Determinants and prospects, ADB Economics Working Paper Series No. 220. Manila, Philippines. Retrieved December 14, 2017 from https://think-asia.org/bitstream/handle/11540/1559/ economics-wp220.pdf? sequence $=1$.

Lien, N. P. (2018). How does governance modify the relationship between public Finance and Economic Growth: A global analysis. VNU Journal of Science: Economics and Business, 34(5E), 39-62. https://doi.org/10.25073/2588-1108/ vnueab. 4165

Lien, N. P. (2015). Impact of institutional quality on tax revenue in developing countries. Asian Journal of Empirical Research, 5(10), 181-195. DOI: 10.18488/ journal.1007/2015.5.10/1007.10.181.195

Link, A. N. and Siegel, D. S. (2003). Technological Change and Competition. London and New York: Routledge - Taylor \& Francis Group. DOI: 10.1108/eb039023.

Mankiw, N.G., Romer, D. \& Weil, D.N. (1992). A contribution to the empirics of economic growth. Quarterly Journal of Economics, May, 407-437.

Méon, P. G. and Weill, L. (2010). Is Corruption an Efficient Grease?. World Development, 38(3), 244-259. https://doi.org/10.1016/j. worlddev.2009.06.004.

Mauro, P. (1995). Corruption and growth. The Quarterly Journal of Economics, 110(3), 681-712.
Pradhan, R. P., Mallik, G., \& Bagchi, T. P. (2018). Information communication technology (ICT) infrastructure and economic growth: A causality evinced by cross-country panel data. IIMB Management Review, 30(1), 91-103. https://doi.org/10.1016/j. iimb.2018.01.001.

Sadykhanova, G., Erezhepova, A., Nurmanova, B., Aitbembetova, A., \& Bimendiyeva, L. (2019). Efficiency of financing hightech industries: The case of Kazakhstan. Journal of Asian Finance, Economics and Business, 6(4), 287-295. https://doi. org/10.13106/jafeb.2019.vol6.no4.287.

Sepehrdoust, H. (2019). Impact of information and communication technology and financial development on economic growth of OPEC developing economies. Kasetsart Journal of Social Sciences, 40(3), 546-551. https://doi.org/10.1016/j. kjss.2018.01.008.

Solow, R. M. (1956). A contribution to the theory of economic growth. The Quarterly Journal of Econometrics, 70(1), 65-94.

Srholec, M. (2007). High-Tech Exports from Developing Countries: A Symptom of Technology Spurts or Statistical Illusion? Review of World Economics, 143(2), 227-255. DOI: 10.1007/s10290-007-0106-Z.

Swan, T. W. (1956). Economic Growth and Capital Accumulation. Economic Record, 32, 334-361.

Ugur, M. (2014). Corruption's direct effects on per-capita income growth: A meta-analysis. Journal of Economic Surveys, 28(3), 472-490. https://doi.org/10.1111/joes.12035.

Ustabaş, A., \& Ersin, Ö. Ö. (2016). The effects of R\&D and high technology exports on economic growth: A comparative cointegration analysis for Turkey and South Korea. In International Conference on Eurasian Economies 2016 (pp.4455). Kaposvar-Hungary: International Conference on Eurasian Economies 2016. https://doi.org/10.36880/c07.01475.

Yoo, S. H. (2008). High-technology exports and economic output: An empirical investigation. Applied Economics Letters, 15(7), 523-525. https://doi.org/10.1080/13504850600721882.

$\mathrm{Vu}, \mathrm{K} . \mathrm{M}$. (2011). ICT as a source of economic growth in the information age: Empirical evidence from the 19962005 period. Telecommunications Policy, 35(4), 357-372. https:// doi.org/10.1016/j.telpol.2011.02.008. 


\section{Appendices}

Table A1: Robustness check

\begin{tabular}{|c|c|c|}
\hline \multirow[t]{2}{*}{ Variables } & \multicolumn{2}{|c|}{ Dynamic Panel data } \\
\hline & $\begin{array}{l}\text { Coef. } \\
\text { Std. Err. }\end{array}$ & $\begin{array}{l}\text { Computed z } \\
\text { Statistic }^{*}\end{array}$ \\
\hline & \multicolumn{2}{|c|}{ Dependent variable: Lg_GDPpp } \\
\hline \multirow[t]{2}{*}{ ICTtexp } & 0.020 & 9.240 \\
\hline & $(0.002)$ & $(0.001)^{\star \star \star}$ \\
\hline \multirow[t]{2}{*}{ ICTimp } & -0.018 & -4.000 \\
\hline & $(0.002)$ & $(0.000)^{\star \star *}$ \\
\hline \multirow[t]{2}{*}{ INF } & 0.0004 & 0.300 \\
\hline & $(0.001)$ & $(0.764)$ \\
\hline \multirow[t]{2}{*}{ ATL } & -0.001 & -8.510 \\
\hline & $(0.000)$ & $(0.000)^{\star \star \star}$ \\
\hline \multirow[t]{2}{*}{$\mathrm{CC}$} & 0.208 & 28.260 \\
\hline & $(0.050)$ & $(0.000)^{\star \star \star *}$ \\
\hline \multirow[t]{2}{*}{ GE } & 0.228 & 2.880 \\
\hline & $(0.039)$ & $(0.005)^{\star \star \star}$ \\
\hline \multirow[t]{2}{*}{ Constant } & 4.161 & 33.150 \\
\hline & $(0.076)$ & $(0.000)^{\star \star \star}$ \\
\hline $\begin{array}{l}\text { Number of } \\
\text { observation }\end{array}$ & & 210 \\
\hline Wald chi2 & & 10095.42 \\
\hline Prob > chi2 & & $(0.000)^{\star \star \star}$ \\
\hline Number of groups & & 20 \\
\hline $\begin{array}{l}\text { Number of } \\
\text { instruments }\end{array}$ & & 19 \\
\hline$A R(2)$ & & 0.971 \\
\hline $\begin{array}{l}\text { Over identification - } \\
\text { Sargan test }\end{array}$ & & 0.419 \\
\hline
\end{tabular}

$z$ statistics in parentheses: ${ }^{*} p<0.1,{ }^{* *} p<0.05,{ }^{* * *} p<0.01$
Table A2: The studied countries

\begin{tabular}{|l|l|}
\hline \multicolumn{1}{|c|}{ Countries } & \multicolumn{1}{c|}{ Countries } \\
\hline 1. Armenia & 12. Nepal \\
\hline 2. Australia & 13. New Zealand \\
\hline 3. Azerbaijan & 14. Palau \\
\hline 4. Brunei Darussalam & 15. Samoa \\
\hline 5. Cambodia & 16. Singapore \\
\hline 6. Fiji & 17. Sri Lanka \\
\hline 7. Georgia & 18. Thailand \\
\hline 8. Hong Kong, China & 19. Tonga \\
\hline 9. Kazakhstan & 20. Turkey \\
\hline 10. Korea, Rep. & 21. Vietnam \\
\hline 11. Malaysia & \\
\hline
\end{tabular}

Originally, the Asian-Pacific region includes as many as 49 countries. However, due to the lack of data in total hours spent for paying taxes (administrative tax level), this paper could not study the following countries: Indonesia, Laos, Myanmar, the Cook Islands, Kiribati, the Marshall Islands, Micronesia, Nauru, Niue, Papua New Guinea, the Solomon Islands, Timor-Leste, Tuvalu, Vanuatu, Kyryz Republic, Tajikistan, Uzbekistan, China, Japan, Mongolia, Taipei, Afghanistan, Bangladesh, Bhutan, India, Maldives, Pakistan, and the Philippines. 